\title{
"Traditional banks against fintech startups: a field investigation of a regional bank in Indonesia"
}

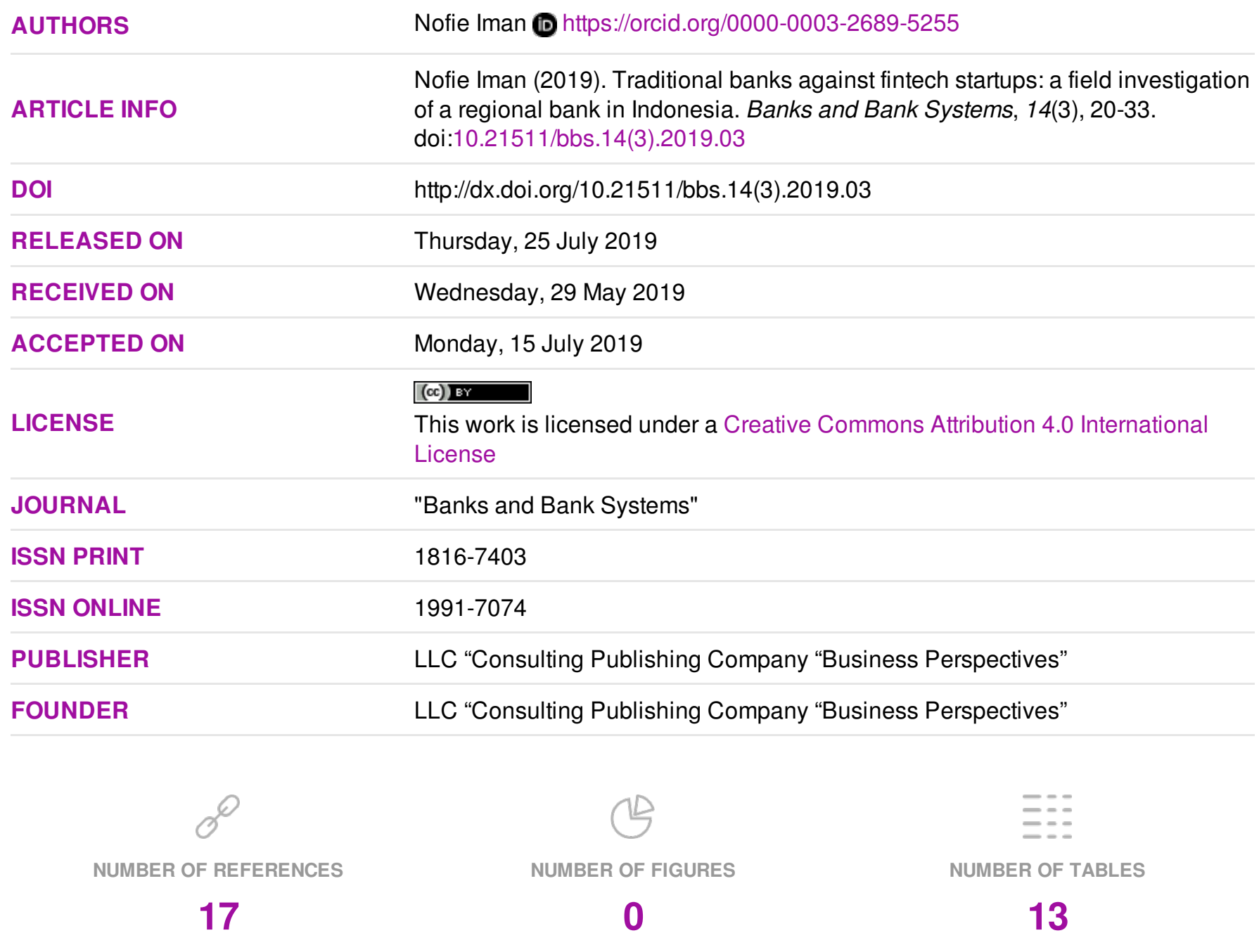

(C) The author(s) 2023. This publication is an open access article. 


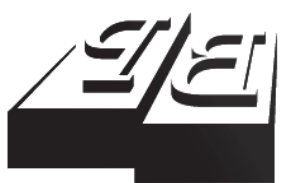

BUSINESS PERSPECTIVES

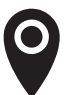

LLC "CPC "Business Perspectives" Hryhorii Skovoroda lane, 10, Sumy, 40022, Ukraine

www.businessperspectives.org

Received on: $29^{\text {th }}$ of May, 2019 Accepted on: $15^{\text {th }}$ of July, 2019

(C) Nofie Iman, 2019

Nofie Iman, Faculty Member, Faculty of Economics and Business, Department of Management, Universitas Gadjah Mada, Indonesia.

\section{(c) (i)}

This is an Open Access article, distributed under the terms of the Creative Commons Attribution 4.0 International license, which permits unrestricted re-use, distribution, and reproduction in any medium provided the original work is properly cited.
Nofie Iman (Indonesia)

\section{TRADITIONAL BANKS AGAINST FINTECH STARTUPS: A FIELD INVESTIGATION OF A REGIONAL BANK IN INDONESIA}

\begin{abstract}
This research examines the way in which traditional banks are competing against the emerging fintech startups. This study identifies driving factors and uniqueness that illustrate the peculiar characteristics of incumbents, analyzes their internal readiness and capabilities, and examines their strategic response against fintech startups. In doing so, this paper examines Small Town Bank (STB $)^{1}$, a regional bank in Indonesia, regarding its ability to innovate. Data are obtained from primary sources through internal and external questionnaires, as well as secondary data. The results of the study indicate that, in general, the bank already has a reasonably good innovation readiness, but there are several aspects that need to be noted, namely: optimization of current services, consolidation, and internal restructuration. Concurrently, while fintech has a very broad and massive technical and managerial impact, it does not mean that incumbent banks and traditional financial services cannot compete.
\end{abstract}

Keywords

JEL Classification

\section{INTRODUCTION}

Fintech, or financial technology, is something new. However, it has and continues to grow very significantly. It also gives a disruptive effect not only in the banking and financial services sector, but also in other sectors. Moreover, this sector is not only dominated by incumbent banks and traditional financial institutions, but also technology-based start-up companies that are very keen to enter and dominate this niche (Gomber et al., 2017).

The terminology of "fintech" or "financial technology" had emerged since the 1990s when Citigroup initiated a project titled "Financial Services Technology Consortium", which aims to facilitate technological collaboration in the financial services industry. The "new" fintech terminology has emerged since 2014 and attracted public attention. Since then, fintech has been used extensively to describe the massive influx of technology, platforms, and ecosystems that make services and products in the financial industry more accessible, more efficient, and affordable for more people.

Throughout its history, the financial industry has been the most significant technology user in the service sector after the telecommunications industry itself (Iman, 2014). Compared to other service sectors, the financial sector is always at the forefront of technology-based in-

1 For confidentiality reasons, this is a fictitious name. 
novation. However, this industry is also locked in by strict regulations, both at national, regional, and international levels. On the other hand, fintech is known as one of the critical innovations that comes at high speed and is driven by information technology and regulatory relaxation (Lee \& Shin, 2018). It offers a promise to change the banking and financial services industry through cutting significant costs, increasingly diverse services, and more stable industrial and market landscape (The Economist, 2015).

In contrast to the wave of innovations that colored the banking industry and financial services before, technological changes that accompanied the presence of fintech were far more diverse: infrastructure, big data, data analytics, and artificial intelligence (Iman, 2018). Not surprisingly, PricewaterhouseCoopers (2016) stated that 83 percent of financial institutions were threatened by fintech. The biggest advances in the fintech industry are in the United States and China. KPMG (2015) stated that 100 fintech companies exist in both countries, 25 of them are engaged in payment and transactions, 22 in lending, 14 in wealth management, and 7 in the insurance sector. Disruptive changes brought by fintech not only directly affect the conventional banking industry, but also other industries that are not even directly related to banking (Wonglimpiyarat, 2017). This has a very broad and massive technical and managerial impact.

Compared to other technology-based innovations that have been occurring in the financial sector, the technological changes brought by fintech this time do not refer to just one thing. Fintech penetrated various fields and subfields such as payment, funding, financing, investment, asset management, banking services, insurance, cryptocurrency (Iman, 2018). It is not surprising that fintech attracted the attention of many actors, not only banks and regulators, but also non-financial industries, start-up companies, and venture capital (Wonglimpiyarat, 2017).

This research attempts to find insights that are useful for industry players and policymakers by focusing on two central questions:

1. What is the dynamics of the fintech industry in Indonesia today?

2. What kind of response should be taken by STB to respond to this dynamics?

In so doing, this paper is organized into the following structure. The next part discusses the conceptual framework used to map fintech and banking in the literature. It then is followed by a review of the methodology used in this research. The results and discussion in this study will be outlined in the next sections, while the last section contains suggestions, as well as concluding remarks.

\section{THEORETICAL REVIEW}

In order to address the aforementioned concerns, this study borrows the diffusion of innovations (DOI) theory and the service quality (SERVQUAL) framework to describe the dynamics of the fintech industry landscape in Indonesia, as well as the organizational information technology/systems innovation models (OITIM), a strategic orientation toward service innovation (SOSI), and enabling mechanism for service innovation (EMSI). A brief description of the conceptual theorem and framework will be elaborated as follows.

First, the conceptual framework of diffusion of innovation (Rogers, 1995) is useful to help us see the effect of the tipping point when a trend spreads exponentially in society. The diffusion process is created through a communication mechanism for an innovation that is disseminated through various channels and members in the social community. In general, the process can be categorized in the following stages:
(1) knowledge;
(2) persuasion;
(3) decisions;
(4) implementation; and
(5) confirmation.

The diffusion process will follow the $S$ curve, where a small portion will become early innovators and 
adopters. Along the way, innovation will be adopted by most early majority, until almost all adopt (late majority) and followed by those laggards.

As one of the technology products, fintech is also suspected of demonstrating a similar pattern as expressed by Rogers (1995). Consumers will first look for information (knowledge) regarding fintech products and services. They will go through the stage of persuasion, which is usually influenced by their environment and media or advertising. They then decide to use fintech products daily, while carrying out a confirmation process with the surrounding environment. The dominant structure of fintech can be obtained from the process of communication and significance, on the one hand, and the process of sanctions and legitimacy, on the other hand. This combination of structures is increasingly relevant considering that fintech does not only involve relationships between providers of fintech products and services, but also government and regulators, venture capital and investors, and industry associations.

Second, it is important for us to understand how far the existing fintech products and services have met the expectations of its users. The gap can be analyzed using the SERVQUAL framework (Parasuraman et al., 1988), a multi-scale measurement instrument that can be used to measure customer perceptions of the services provided. Customers will assess whether the services they have obtained have not or have exceeded their expectations. By comparing these indicators, we can conclude how high the current level of customer satisfaction is. The measurement is divided into five service qualities and 22 questions that include tangibles, reliability, responsiveness, assurance, and empathy.

Finally, and most importantly, the framework of organizational information technology/systems innovation model (OITIM), a strategic orientation toward service innovation (SOSI), and enabling mechanism for service innovation (EMSI). OITIM looks at the readiness of innovation in an organization through several factors: organizational values and goals, resources, organizational processes, operations, technology, personnel and skills, and knowledge (Snyder-Halpern, 2001). SOSI assesses organizational readiness from two dimensions: strategic investment and risk tolerance, while EMSI measures organizational readiness from four dimensions: superior service innovation, collaboration in organizations, innovation experience, and information technology experience (Yen et al., 2012). These aspects become multidimensional constructs that are accurate enough to measure the organization's internal readiness in developing innovations such as fintech.

\section{METHODS}

To ensure the research objectives are achieved, and the research questions are answered thoroughly, the right methodology is necessary (Creswell, 2003). For this reason, this study was designed using a set of approaches and analysis that were felt to be most appropriate to answer research questions (Bell et al., 2018). In addition, this study also involved various primary and secondary data sources in obtaining an accurate and comprehensive picture of the phenomena (Miles \& Huberman, 1984).

In general, this research activity was designed as a descriptive-exploratory research (Creswell, 2003). It is directed at exploring information and providing an explanation of the dynamics of fintech occurring in Indonesia. The data and information used are qualitative and quantitative. All data and information obtained will go through the triangulation phase to verify and match existing phenomena and reality (Denzin, 1989). The data were gathered through desk research, interviews with key informants at STB, as well as a direct observation with fintech users in Indonesia (see Table 1).

Table 1. External and internal analysis instruments

\begin{tabular}{|c|c|}
\hline Instrument & Sources \\
\hline Desk research & $\begin{array}{l}\text { Secondary literature, journals, magazines, } \\
\text { newspapers, etc. }\end{array}$ \\
\hline Interviews & $\begin{array}{l}\text { Fintech players, policy makers, industrial } \\
\text { associations }\end{array}$ \\
\hline $\begin{array}{l}\text { Survey and } \\
\text { observations }\end{array}$ & $\begin{array}{l}\text { Users of fintech applications and STB } \\
\text { customers }\end{array}$ \\
\hline $\begin{array}{l}\text { Survey and } \\
\text { interviews }\end{array}$ & Supervisors, managers, and executives of STB \\
\hline Internal FGD & Managers, directors, and executives of STB \\
\hline $\begin{array}{l}\text { Reflective } \\
\text { workshop }\end{array}$ & Directors and executives of STB \\
\hline
\end{tabular}


Several questionnaires were distributed to the general public to get an overview of the process of adopting and diffusing fintech products and services in Indonesia. The questionnaire was developed by adopting the conceptual framework of diffusion of innovation (Rogers, 1995) and the SERVQUAL framework (Parasuraman et al., 1988). The questionnaire then be analyzed and interpreted further to answer research questions and formulate appropriate conclusions (Bell et al., 2018).

The selection of samples of fintech users is done using snowball sampling. Respondents were asked to fill out questionnaires on fintech products and services that they were currently using and the level of satisfaction they felt. Demographic information such as age, gender, level of education, income, etc. are also collated for further analysis. The study also distributed questionnaires to STB customers spread across cities and regencies for further analysis. Before being distributed, the questionnaire was pilot tested to see the validity and reliability of the instrument.

Meanwhile, to analyze the internal conditions and innovation capabilities of STB, several questionnaires were distributed to employees at STB, both those involved in the IT division and those in non-IT divisions. This study uses the conceptual framework of OITIM (Snyder-Halpern, 2001). Before being distributed, the questionnaire was discussed with the STB research team to ensure compliance and confidentiality. Next, the questionnaire was distributed online and offline by the author along with the STB research team. Through this process of discussion and workshop, it is expected that more comprehensive information will be obtained to develop strategic recommendations for STB, as well as other incumbent banks. To minimize bias, reduce "spectator's account", and improve the quality of research, this activity follows structured research protocols (Creswell, 2003; Schoefield, 1990). The focus of this research is to get a deep, comprehensive, specific, and relevant understanding of the research goals and objectives.

\section{ANALYSIS OF THE FINDINGS}

The "new" fintech was developed so fast in Indonesia since the 2010s as a result of the development of very massive information and com- munication technology. This condition shows that Indonesia is quite a digital country. Together with China and India, Indonesia is an innovator in technology development (PWC, 2016). There are various types of fintech business, according to the central bank (Bank Indonesia). The classification of fintech in Indonesia is divided into 4 (four), namely:

(1) crowdfunding and peer to peer (P2P) lending;

(2) market aggregator;

(3) risk and investment management; and

(4) payment, clearing and settlement.

Unfortunately, fintech's role in financial inclusion, as expected by many parties, seems not to be fully implemented, since most of those fintech startups are headquartered in Jakarta (Iman, 2018). However, despite its criticism, payment transactions and financing transactions through fintech in Indonesia show a very significant growth rate. For example, fintech payment transactions per 2015 were only USD 12.0 billion, but in 2017, they have reached USD 18.6 billion and are expected to break the USD 36.6 billion mark in 2021. Meanwhile, fintech financing transactions in 2015 were only worth USD 12.0 billion, but grew to USD 18.6 billion in 2017 and are estimated to reach USD 37.1 billion in 2021.

\subsection{External environmental analysis}

Of all questionnaires being distributed, 316 questionnaires were damaged, empty, incomplete, and cannot be analyzed further. Thus, the usable and verified questionnaires for further analysis totaled 521. In general, the respondents' demographics from the research can be seen in Table 2. 51.2\% of the respondents were men, while the remaining $48.8 \%$ were women. The majority of respondents were married (68.5\%) and aged $26-30$ years old (32.9\%), followed by those aged 31-35 years old (17.9\%) and 21-25 years old (16.8\%). The respondents are mostly state/regional enterprise employees (27.4\%), private employees (26.5\%), and civil servants $(24.7 \%)$.

Most of the respondents have an undergraduate degree (64.7\%). Thus, it can be assumed that the majority of respondents already have a background in banking knowledge, an understanding 
Table 2. Respondent demographic profile

\begin{tabular}{|c|c|c|}
\hline Variable & Item & Percentage \\
\hline \multirow{2}{*}{ Gender } & Male & 51.2 \\
\hline & Female & 48.8 \\
\hline \multirow{2}{*}{ Marital status } & Married & 68.5 \\
\hline & Other & 31.5 \\
\hline \multirow{9}{*}{ Age } & $<15$ & 0.3 \\
\hline & $16-20$ & 3.8 \\
\hline & $21-25$ & 16.8 \\
\hline & $26-30$ & 32.9 \\
\hline & $31-35$ & 17.9 \\
\hline & $36-40$ & 8.2 \\
\hline & $41-45$ & 9.1 \\
\hline & $46-60$ & 10.3 \\
\hline & $>60$ & 0.6 \\
\hline \multirow{7}{*}{ Employment status } & Private employee & 26.5 \\
\hline & $\begin{array}{l}\text { Regional government } \\
\text { employee }\end{array}$ & 27.4 \\
\hline & Civil servant & 24.7 \\
\hline & Police and military & 2.1 \\
\hline & Entrepreneur & 9.7 \\
\hline & Students & 6.5 \\
\hline & Not working & 3.2 \\
\hline \multirow{7}{*}{$\begin{array}{l}\text { Educational } \\
\text { background }\end{array}$} & Elementary school & 0.3 \\
\hline & Junior high school & 0.6 \\
\hline & Senior high school & 17.4 \\
\hline & Diploma (D1/D3) & 8.2 \\
\hline & Undergraduate & 64.7 \\
\hline & Postgraduate & 8.2 \\
\hline & Doctorate & 0.6 \\
\hline \multirow{37}{*}{ Residency } & City A & 4.1 \\
\hline & City B & 3.5 \\
\hline & City C & 3.8 \\
\hline & City D & 0.3 \\
\hline & City E & 2.9 \\
\hline & City F & 3.8 \\
\hline & City G & 1.8 \\
\hline & City $\mathrm{H}$ & 2.9 \\
\hline & City ! & 1.5 \\
\hline & City J & 3.8 \\
\hline & City K & 5.6 \\
\hline & City L & 1.5 \\
\hline & City M & 2.9 \\
\hline & City N & 1.5 \\
\hline & City O & 2.6 \\
\hline & City P & 0.3 \\
\hline & City 0 & 4.1 \\
\hline & City R & 1.2 \\
\hline & City S & 2.4 \\
\hline & City T & 2.4 \\
\hline & City U & 4.4 \\
\hline & City V & 1.2 \\
\hline & City W & 3.5 \\
\hline & City $X$ & 2.4 \\
\hline & City Y & 1.8 \\
\hline & City z & 2.9 \\
\hline & City 1 & 2.9 \\
\hline & City 2 & 3.5 \\
\hline & City 3 & 2.4 \\
\hline & City 4 & 0.6 \\
\hline & City 5 & 0.3 \\
\hline & City 6 & 5.3 \\
\hline & City 7 & 6.5 \\
\hline & City 8 & 2.4 \\
\hline & City 9 & 2.1 \\
\hline & City 10 & 4.4 \\
\hline & City 11 & 0.6 \\
\hline
\end{tabular}

of technology products, and some sort of knowledge in English, which is commonly used in fintech products and services. Respondents also widely spread in various regions in the province. Therefore, the sample obtained from this research can be considered to be quite representative and normally distributed. The majority also claimed to spend monthly electricity costs between $\mathrm{Rp}$ 50,000 to $\mathrm{Rp} 200,000$, or 48.9 percent $^{2}$. This is also in line with their daily expenditure, the majority of which ranges from $\mathrm{Rp} 50,000$ to $\mathrm{Rp} 150,000$, or $55.3 \%$. Most respondents also claimed to use the internet quite intensely. This is also confirmed by their monthly data expenditures: Rp 75,000 Rp 100,000 (27.9\%) and Rp 100,000 - Rp 125,000 (20.9\%) (see Table 3).

As can be seen, most respondents are familiar with fintech products and services, but are still focused on products and services offered by online transportation service providers (Grabpay, Gopay, Ovo) and e-commerce services (Tokopedia, Bukadompet). They use fintech products and services for payment purposes $(76.4 \%)$ with varying intensity (starting from every day to several times a month). The majority of transactions carried out amounted from Rp 100,000 to Rp 500,000 per transaction (47.9\%).

Respondents in this survey claimed to have known fintech from the Internet (32.1\%), followed by social media $(28.7 \%)$, and friends and family (19.4\%). The power of advertising is not too strong, because it only contributes $18.4 \%$. This is in line with the diffusion innovation theorem (Rogers, 1995), which states that the social environment has a strong influence in determining and forming patterns of adoption of technology products such as fintech.

Furthermore, the majority of respondents claimed to be satisfied with the fintech products and services they are currently using (99.4\%). Besides being a customer of STB (46.4\%), they also become customers at other banks such as BRI (18.1\%), Bank Mandiri (12.4\%), and BCA (11.3\%). This indicates that the customer may not be too loyal to one particular product and thus tends to have more than one account in a different bank. 
Table 3. Respondent demographic profile

\begin{tabular}{|c|c|c|}
\hline Variable & Item & Percentage \\
\hline \multirow{11}{*}{ Monthly electricity bills } & $<\operatorname{Rp~50,000}$ & 6.8 \\
\hline & Rp 50,000-100,000 & 16.8 \\
\hline & $R p 100,000-150,000$ & 14.7 \\
\hline & $R p 150,000-200,000$ & 17.4 \\
\hline & $R p 200,000-250,000$ & 10.0 \\
\hline & $R p 250,000-300,000$ & 7.4 \\
\hline & Rp 300,000-350,000 & 4.7 \\
\hline & $R p 350,000-400,000$ & 6.5 \\
\hline & $R p 400,000-450,000$ & 1.8 \\
\hline & $R p 450,000-500,000$ & 5.0 \\
\hline & $>\operatorname{Rp~500,000}$ & 9.1 \\
\hline \multirow{11}{*}{ Average daily expenditures } & $<\operatorname{Rp} 50,000$ & 7.4 \\
\hline & $\operatorname{Rp} 50,000-100,000$ & 34.1 \\
\hline & $R p 100,000-150,000$ & 21.2 \\
\hline & $R p$ 150,000-200,000 & 11.5 \\
\hline & $R p 200,000-250,000$ & 5.3 \\
\hline & $R p 250,000-300,000$ & 2.6 \\
\hline & $R p 300,000-350,000$ & 3.2 \\
\hline & $R p 350,000-400,000$ & 2.4 \\
\hline & $R p 400,000-450,000$ & 1.8 \\
\hline & $R p 450,000-500,000$ & 1.8 \\
\hline & $>\operatorname{Rp~500,000}$ & 8.8 \\
\hline \multirow{4}{*}{ The use of Internet } & Rarely & 4.4 \\
\hline & Adequate & 10.3 \\
\hline & Often & 42.4 \\
\hline & Very often & 42.9 \\
\hline \multirow{9}{*}{ Monthly internet data expenditures } & $<\operatorname{Rp} 25,000$ & 1.2 \\
\hline & $R p 25,000-50,000$ & 5.9 \\
\hline & Rp 50,000-75,000 & 17.9 \\
\hline & $R p 75,000-100,000$ & 27.9 \\
\hline & $R p 100,000-125,000$ & 20.9 \\
\hline & $R p 125,000-150,000$ & 7.6 \\
\hline & $R p 150,000-175,000$ & 4.1 \\
\hline & $R p 175,000-200,000$ & 5.0 \\
\hline & $>\operatorname{Rp~200,000}$ & 9.4 \\
\hline \multirow{20}{*}{$\begin{array}{l}\text { Name of fintech products/services } \\
\text { being use }\end{array}$} & Amartha & 0.3 \\
\hline & Artajasa & 0.4 \\
\hline & Bareksa & 0.1 \\
\hline & Bukadompet & 10.3 \\
\hline & Crowdo & 0.3 \\
\hline & Doku & 0.9 \\
\hline & Gopay & 30.5 \\
\hline & Grabpay & 17.2 \\
\hline & Investree & 0.1 \\
\hline & Ipaymu & 0.3 \\
\hline & Kartuku & 0.7 \\
\hline & Koinworks & 0.1 \\
\hline & Midtrans & 0.1 \\
\hline & Modalku & 0.1 \\
\hline & Ovo & 11.7 \\
\hline & Pinjam.co.id & 0.1 \\
\hline & Rintis Sejahtera (Prima) & 0.1 \\
\hline & Tokopedia & 21.9 \\
\hline & Uangku & 0.3 \\
\hline & $\begin{array}{l}\text { Others (Shopee, Dana, Internet Banking, SMS Banking, Lazada, } \\
\text { PayFazz, PayLater, Apps24, Olk, Zilingo, Sepulsa, Bli-Bli, Akulaku) }\end{array}$ & 4.3 \\
\hline
\end{tabular}


Table 3 (cont.). Respondent demographic profile

\begin{tabular}{|c|c|c|}
\hline Variable & Item & Percentage \\
\hline \multirow{8}{*}{ Category of fintech products/services being use } & Lending & 7.7 \\
\hline & Payment & 76.4 \\
\hline & Point of sales & 2.6 \\
\hline & Crowdfunding & 1.0 \\
\hline & Investment & 6.9 \\
\hline & Asset management & 1.3 \\
\hline & Insurance & 3.6 \\
\hline & Others & 0.5 \\
\hline \multirow{6}{*}{ Intensity of using fintech } & Everyday & 16.8 \\
\hline & Several times a week & 33.5 \\
\hline & Once in a week & 4.7 \\
\hline & Several times a month & 28.2 \\
\hline & Once in a month & 6.5 \\
\hline & Once in several months & 10.3 \\
\hline \multirow{5}{*}{ Average value of fintech transactions } & $<$ Rp 100,000/transactions & 37.9 \\
\hline & Rp 100,000-500,000/transactions & 47.9 \\
\hline & Rp 500,000-1,000,000/transactions & 10.0 \\
\hline & Rp $1,000,000-5,000,000 /$ transactions & 2.9 \\
\hline & $>$ Rp 5,000,000/transactions & 1.2 \\
\hline \multirow{5}{*}{ How the respondents know about fintech } & Advertisement & 18.4 \\
\hline & Friends/family & 19.4 \\
\hline & Internet & 32.1 \\
\hline & Social media & 28.7 \\
\hline & Magazines/newspapers & 1.5 \\
\hline \multirow{2}{*}{ Are the respondents satisfied with fintech } & Yes & 99.4 \\
\hline & No & 0.6 \\
\hline \multirow{8}{*}{ What bank customers are the respondents } & Bank Rakyat Indonesia & 18.1 \\
\hline & Bank Mandiri & 12.4 \\
\hline & STB & 46.8 \\
\hline & Bank Negara Indonesia & 9.4 \\
\hline & CIMB Niaga & 0.9 \\
\hline & Bank Central Asia & 11.3 \\
\hline & Muamalat & 0.0 \\
\hline & Other & 1.1 \\
\hline
\end{tabular}

I analyze the data in more depth (see Table 4). The majority of customers already have savings products from STB (68.1\%). They have been customers for more than five years (37.4\%) and access STB's products and services through branch offices $(30.2 \%)$. This indicates that STB customers are quite loyal and respect physical and personal interactions. Confidence and trust factors may be one important factor for STB customers in obtaining financial services.

Another thing that is quite interesting is that STB customers who are using internet banking are $17.1 \%$. The fact that Internet banking at STB has just been launched since 2018 shows that its growth cannot be underestimated. This also indicates that STB customers are ready to use technology-based services such as Internet banking and fintech, although not all STB customers are young or highly educated indeed.
Furthermore, I conduct a more specific analysis of the pattern of adoption and diffusion of fintech products and services. Borrowing from the diffusion theory of innovation (Rogers, 1995), I divide these factors into 4 (four) things:

(1) superiority over other products and services (relative advantage/compatibility);

(2) simplicity of products and services (complexity/ simplicity);

(3) trialability; and

(4) ease of seeing features and benefits offered (observability).

Table 5 shows the analysis of the results of the correlation using the Principal Component Analysis and Varimax rotation method using Kaiser 
Table 4. Demographic profile of STB customer respondents

\begin{tabular}{|c|c|c|}
\hline Variable & Item & Percentage \\
\hline \multirow{6}{*}{ STB's products being use } & Giro & 4.4 \\
\hline & Saving accounts & 68.1 \\
\hline & Time deposits & 9.2 \\
\hline & Credits for business & 3.5 \\
\hline & Credits for personal consumption & 13.1 \\
\hline & Other & 1.7 \\
\hline \multirow{4}{*}{ How long have been a STB's customer } & Less than a year & 14.6 \\
\hline & Between 1 and 3 years & 26.2 \\
\hline & Between 3 and 5 years & 21.8 \\
\hline & More than 5 years & 37.4 \\
\hline \multirow{8}{*}{ How to access and obtain STB products and services } & Branch office & 30.2 \\
\hline & Sub-branch office & 10.3 \\
\hline & Cash office & 8.2 \\
\hline & Payment point & 2.2 \\
\hline & ATM & 25.9 \\
\hline & CDM & 0.7 \\
\hline & Cash mobile & 5.5 \\
\hline & Internet banking & 17.1 \\
\hline
\end{tabular}

Table 5. Rotated component matrix

\begin{tabular}{|c|c|c|c|c|}
\hline Statement & $\begin{array}{c}\text { Factor } 1: \text { relative } \\
\text { advantage/compatibility }\end{array}$ & $\begin{array}{c}\text { Factor 2: complexity/ } \\
\text { simplicity }\end{array}$ & $\begin{array}{l}\text { Factor 3: } \\
\text { trialability }\end{array}$ & $\begin{array}{c}\text { Factor 4: } \\
\text { observability }\end{array}$ \\
\hline PB1 & 0.735 & 0.187 & 0.084 & 0.077 \\
\hline PB2 & 0.673 & 0.168 & 0.228 & 0.185 \\
\hline PB3 & 0.764 & 0.077 & 0.062 & 0.279 \\
\hline PB4 & 0.736 & 0.114 & 0.210 & 0.126 \\
\hline PB5 & 0.654 & 0.166 & 0.280 & 0.232 \\
\hline PB6 & 0.656 & 0.199 & 0.171 & 0.209 \\
\hline PB7 & 0.702 & 0.246 & 0.068 & 0.177 \\
\hline PB8 & 0.444 & 0.299 & 0.464 & 0.131 \\
\hline PB9 & 0.690 & 0.070 & 0.175 & 0.258 \\
\hline PB10 & 0.618 & 0.239 & 0.300 & 0.145 \\
\hline PB11 & 0.230 & 0.687 & 0.188 & 0.109 \\
\hline PB12 & 0.169 & 0.768 & 0.197 & 0.126 \\
\hline PB13 & 0.188 & 0.723 & 0.143 & 0.252 \\
\hline PB14 & 0.164 & 0.806 & 0.191 & 0.124 \\
\hline PB15 & 0.120 & 0.809 & 0.193 & 0.088 \\
\hline PB17 & 0.170 & 0.781 & 0.205 & 0.173 \\
\hline PB18 & 0.139 & 0.792 & 0.204 & 0.173 \\
\hline PB19 & 0.208 & 0.400 & 0.666 & 0.092 \\
\hline PB20 & 0.210 & 0.411 & 0.666 & 0.108 \\
\hline PB21 & 0.331 & 0.111 & 0.560 & 0.300 \\
\hline PB22 & 0.183 & 0.190 & 0.679 & 0.273 \\
\hline PB23 & 0.177 & 0.304 & 0.699 & 0.231 \\
\hline PB24 & 0.179 & 0.141 & 0.211 & 0.707 \\
\hline PB25 & 0.463 & 0.040 & -0.006 & 0.586 \\
\hline PB26 & 0.234 & 0.304 & 0.332 & 0.537 \\
\hline PB27 & 0.151 & 0.475 & 0.343 & 0.528 \\
\hline PB28 & 0.509 & 0.141 & 0.141 & 0.569 \\
\hline PB29 & 0.344 & 0.241 & 0.152 & 0.651 \\
\hline PB30 & 0.238 & 0.253 & 0.304 & 0.618 \\
\hline Mean & 3.50 & 3.88 & 3.73 & 3.54 \\
\hline Standard deviation & 0.92 & 0.84 & 0.85 & 0.86 \\
\hline Cronbach alpha & 0.911 & 0.922 & 0.846 & 0.865 \\
\hline
\end{tabular}

Note: extraction method: Principal Component Analysis. Rotation method: Varimax with Kaiser Normalization. Rotation converged in 6 iterations. 
Table 6. Correlation matrix

\begin{tabular}{l|c|c|c|c|c}
\hline \multicolumn{1}{c}{ Correlation } & $\begin{array}{c}\text { Relative advantage/ } \\
\text { compatibility }\end{array}$ & $\begin{array}{c}\text { Complexity/ } \\
\text { simplicity }\end{array}$ & Trialability & Observability & $\begin{array}{c}\text { Perceived benefits } \\
\text { of adopting fintech }\end{array}$ \\
\hline $\begin{array}{l}\text { Relative advantage/ } \\
\text { compatibility }\end{array}$ & 1 & $0.506^{* *}$ & $0.613^{* *}$ & $0.713^{* *}$ & $0.882^{* *}$ \\
\hline Complexity/ simplicity & - & 1 & $0.631^{* *}$ & $0.568^{* *}$ & $0.786^{* *}$ \\
\hline Trialability & - & - & 1 & $0.659^{* *}$ & $0.822^{* *}$ \\
\hline $\begin{array}{l}\text { Observability } \\
\text { Perceived benefits of }\end{array}$ & - & - & - & 1 & $0.868^{* *}$ \\
adopting fintech & - & - & - & - & 1 \\
\hline
\end{tabular}

Note: ${ }^{* *}$ correlation is significant at 0.01 level (2-tailed).

Normalization. The PB16 statement is excluded from the analysis, because the factor loading value is less than 0.4, while other statements met the methodological criteria.

From Table 5, it can be seen that the largest average score is the product simplicity of 3.88 , followed by the trialability of 3.73 . This number supports the findings above, which imply that fintech products and services are expected to be easy to understand and can be tried first by prospective users. Correspondingly, it is clear that the correlation between the factors driving the adoption of fintech products and services is positive and quite significant (Table 6). The strongest factor that supports user perceptions is the relative advantage of 0.882 , followed by the observability of 0.868 . These two factors are closely related and considered to be a key factor in the development of fintech innovations.

To get a more detailed picture, I then examine in depth the respondents who have used fintech products and services. I am interested in seeing how the gap occurs between expectations and perceptions of the fintech products and services they use (see Table 7). A positive gap means that existing products and services have been able to meet expectations. Conversely, a negative gap means consumers or users are not satisfied with the fintech products and services they use.

Table 7. Gap analysis between expectations and perceptions

\begin{tabular}{|c|c|c|c|c|}
\hline Factors & Expectation & Perception & Gap & $\begin{array}{c}\text { Average dimension } \\
\text { score }\end{array}$ \\
\hline \multirow{4}{*}{ Tangibility } & 4.10 & 3.90 & -0.20 & \multirow{4}{*}{-0.1032} \\
\hline & 3.94 & 3.86 & -0.08 & \\
\hline & 3.74 & 3.71 & -0.02 & \\
\hline & 4.02 & 3.91 & -0.11 & \\
\hline \multirow{5}{*}{ Reliability } & 3.90 & 3.85 & -0.06 & \multirow{5}{*}{-0.1678} \\
\hline & 3.96 & 3.76 & -0.20 & \\
\hline & 4.02 & 3.82 & -0.21 & \\
\hline & 4.04 & 3.86 & -0.18 & \\
\hline & 4.02 & 3.82 & -0.19 & \\
\hline \multirow{4}{*}{ Responsiveness } & 3.99 & 3.79 & -0.20 & \multirow{4}{*}{-0.2025} \\
\hline & 4.07 & 3.89 & -0.18 & \\
\hline & 4.11 & 3.86 & -0.25 & \\
\hline & 3.90 & 3.72 & -0.18 & \\
\hline \multirow{4}{*}{ Assurance } & 4.04 & 3.77 & -0.27 & \multirow{4}{*}{-0.2538} \\
\hline & 4.12 & 3.92 & -0.20 & \\
\hline & 4.11 & 3.87 & -0.24 & \\
\hline & 4.14 & 3.83 & -0.30 & \\
\hline \multirow{5}{*}{ Empathy } & 3.98 & 3.69 & -0.28 & \multirow{5}{*}{-0.2407} \\
\hline & 4.00 & 3.81 & -0.20 & \\
\hline & 3.90 & 3.70 & -0.20 & \\
\hline & 4.05 & 3.80 & -0.24 & \\
\hline & 4.00 & 3.72 & -0.28 & \\
\hline \multicolumn{4}{|c|}{ Average unweighted score } & -0.1936 \\
\hline
\end{tabular}


As shown in Table 7, all gaps are negative. The biggest negative contributing factor is assurance $(-0.2538)$, indicating that fintech users do not feel safe and confident for what they are currently using. This number is also correlated with the empathy factor $(-0.2407)$ and the responsiveness factor $(-0.2020)$. It indicates that the current fintech providers are perceived as unable to answer the needs of users in an empathic and responsive manner. The weighted average gap is also quite large $(-3.805)$ with the highest contributing factors being assurance $(-4.71)$, followed by responsiveness (-4.33) and empathy (-4.26). It is safe to say that fintech users have not been satisfied with the assurance, responsiveness, and empathy level.

Table 8. Gap analysis between expectations and weighted perceptions

\begin{tabular}{l|c|c|c}
\hline \multicolumn{1}{c}{ Factors } & $\begin{array}{c}\text { Average } \\
\text { dimension } \\
\text { score }\end{array}$ & $\begin{array}{c}\text { Dimension } \\
\text { weight }\end{array}$ & $\begin{array}{c}\text { Weighted } \\
\text { score }\end{array}$ \\
\hline Tangibility & -0.1032 & 21.388 & -2.21 \\
\hline Reliability & -0.1678 & 20.960 & -3.52 \\
\hline Responsiveness & -0.2025 & 21.393 & -4.33 \\
\hline Assurance & -0.2538 & 18.539 & -4.71 \\
\hline Empathy & -0.2407 & 17.720 & -4.26 \\
\hdashline Average & & & -3.805 \\
weighted score & & & \\
\hline
\end{tabular}

If STB wants to develop its fintech products and services, it would be good to focus on the dimensional factors mentioned above (tangibility, reliability, responsiveness, assurance, and empathy). As an initial reference, STB can see the dimensions level from the most important to the least important according to the dimension weight (Table 8). The description above can help to understand what dimensions should be the top priority of STB in order to build a competitive fintech business that is in line with the expectations in the market.

\subsection{Internal capability analysis}

STB is a regional bank that is committed to improve the local economy. STB was established in 1963, pioneered by the regional government along with community leaders and private business leaders based on the need for a financial institution, which specifically assisted the government in implementing development plan in the region. STB also has services that are widespread in many areas (see Table 9). Overall, STB has 37 conventional branches and four sharia branches. The existence of STB is also supported by sub-branch offices, cash offices, payment points, ATMs, CDM, and many mobile cash cars. This is evidenced by the award achieved by STB as the top bank within BUKU-III category in $2018^{3}$. STB was also selected as the best bank among 55 public banks in the BUKU-III category, which was launched by Info Bank magazine.

Furthermore, I analyze the internal readiness of STB staff in carrying out technology-based innovations such as fintech. More specifically, I was interested in testing STB's internal readiness in responding to this technology-based innovation. By borrowing the OITIM theorem (SnyderHalpern, 2001), online questionnaires were compiled and distributed internally for further analysis. Filling out questionnaires involves all STB employees, both those related to IT and non-IT (see Table 10).

As shown in Table 11, in general, STB's internal employees feel quite ready and confident with fintech innovation. The biggest score is in administrative support and values or goals of 5.1, while the lowest score is in the knowledge aspect (4.5). Obviously, this has to be the central attention of STB in improving its internal capabilities.

Referring to the OITIM scale (1 to 7), it can be seen that the scores obtained indicate that STB's internal employees already have a high level of innovation readiness (4.9). Indeed, the knowledge factor that has the lowest score needs more attention to realize STB's innovation potential. Thus, in order to get a more comprehensive picture, I conducted an in-depth analysis by separating respondents from information technology (IT) backgrounds and those who are not from IT divisions. The results of the cluster analysis are shown in Table 12 and Table 13.

3 Bank Indonesia classifies commercial banks operating in the country into four categories according to the size of their core capital: Bank Umum Kegiatan Usaha (BUKU) or Commercial Banks Business Activities Category I, II, III, and IV. BUKU-III is a bank with core capital between Rp 5 trillion and Rp 30 trillion. 
Table 9. Number of STB networks (September 2018)

Source: STB internal documents.

\begin{tabular}{|c|c|c|c|c|}
\hline No. & Type & Conventional & Sharia & Total \\
\hline 1 & Branch office & 37 & 4 & 41 \\
\hline 2 & Sub-branch office & 123 & 11 & 134 \\
\hline 3 & Cash office & 155 & 10 & 165 \\
\hline 4 & Payment point & 298 & 2 & 300 \\
\hline 5 & ATM & 706 & 0 & 706 \\
\hline 6 & CDM & 7 & 0 & 7 \\
\hline 7 & Cash mobile + ATM & 35 & 4 & 39 \\
\hline
\end{tabular}

Table 10. Descriptive information of STB internal

\begin{tabular}{|c|c|c|}
\hline Variable & Item & Number \\
\hline \multirow{2}{*}{ Gender } & Male & 77 \\
\hline & Female & 23 \\
\hline \multirow{4}{*}{ Age } & $<25$ & 5 \\
\hline & $25-34$ & 40 \\
\hline & $35-45$ & 28 \\
\hline & $>45$ & 27 \\
\hline \multirow{3}{*}{ Educational background } & Diploma & 2 \\
\hline & Undergraduate & 77 \\
\hline & Postgraduate & 21 \\
\hline \multirow{3}{*}{ Length of employment at STB } & $1-5$ years & 40 \\
\hline & $5-10$ years & 16 \\
\hline & $>10$ years & 44 \\
\hline \multirow{5}{*}{ Experience in IT } & None & 49 \\
\hline & Low & 6 \\
\hline & Adequate & 35 \\
\hline & High & 6 \\
\hline & Very high & 4 \\
\hline \multirow{14}{*}{ Work unit } & Technology and information systems & 30 \\
\hline & Network and services & 4 \\
\hline & Business development and planning & 8 \\
\hline & Treasury and international & 7 \\
\hline & General affairs & 7 \\
\hline & Human resources & 7 \\
\hline & Sharia & 5 \\
\hline & Marketing - consumer retail & 5 \\
\hline & Consumer banking and retail business & 5 \\
\hline & Marketing - corporate account & 5 \\
\hline & Corporate and commercial banking & 5 \\
\hline & Risk management & 5 \\
\hline & Corporate secretary & 4 \\
\hline & Training & 3 \\
\hline \multirow{2}{*}{ Type of work } & Non-IT related & 66 \\
\hline & IT related & 34 \\
\hline
\end{tabular}

Table 11. Internal readiness analysis

\begin{tabular}{l|c|c|c}
\multicolumn{1}{c|}{ Factors } & Standard deviation & Mean & "Do not know", \% \\
\hline Resources & 1.69 & 4.9 & 9 \\
End users & 1.71 & 5.0 & 6 \\
\hline Technology & 1.71 & 4.6 & 9 \\
\hline Knowledge & 1.65 & 4.5 & 12 \\
Process & 1.84 & 5.0 & 4 \\
Values and goals & 1.75 & 5.1 & 2 \\
Management structure & 1.66 & 4.8 & 8 \\
Administrative support & 1.51 & 5.1 & 10 \\
Total & 4.9 & & \\
\hline
\end{tabular}


Table 12. Analysis of mean internal readiness

\begin{tabular}{|c|c|c|c|c|}
\hline Factors & $\begin{array}{c}\text { Mean } \\
\text { (non-IT, } n=66)\end{array}$ & $\begin{array}{c}\text { Mean } \\
(\mathrm{IT}, n=34)\end{array}$ & $\begin{array}{c}\text { Mean } \\
\text { difference }\end{array}$ & $\begin{array}{c}\text { Mean total } \\
(n=100)\end{array}$ \\
\hline Resources & 4.8 & 5.1 & 0.3 & 4.9 \\
\hline End users & 5.1 & 4.8 & 0.3 & 5.0 \\
\hline Technology & 4.6 & 4.6 & 0.0 & 4.6 \\
\hline Knowledge & 4.5 & 4.7 & 0.2 & 4.5 \\
\hline Process & 5.0 & 4.8 & 0.2 & 5.0 \\
\hline Values and goals & 5.2 & 4.9 & 0.3 & 5.1 \\
\hline Management structure & 4.9 & 4.6 & 0.3 & 4.8 \\
\hline Administrative support & 5.1 & 5.2 & 0.1 & 5.1 \\
\hline
\end{tabular}

Table 13. Analysis of "Do not know" internal readiness

\begin{tabular}{|c|c|c|c|c|}
\hline Factors & $\begin{array}{c}\text { "Do not know" } \\
\text { (non-IT), \% }\end{array}$ & $\begin{array}{l}\text { "Do not know" } \\
\text { (IT-related), \% }\end{array}$ & $\begin{array}{c}\text { "Do not know" } \\
\text { (Total), \% }\end{array}$ & $\begin{array}{c}\text { Mean total } \\
(n=100)\end{array}$ \\
\hline Resources & 11 & 5 & 9 & 4.9 \\
\hline End Users & 6 & 5 & 6 & 5.0 \\
\hline Technology & 10 & 6 & 9 & 4.6 \\
\hline Knowledge & 15 & 5 & 12 & 4.5 \\
\hline Process & 4 & 3 & 4 & 5.0 \\
\hline Values and goals & 2 & 3 & 2 & 5.1 \\
\hline Management structure & 9 & 6 & 8 & 4.8 \\
\hline Administrative support & 12 & 6 & 10 & 5.1 \\
\hline
\end{tabular}

As shown in Tables 12 and 13, there are significant differences between IT employees and non-IT employees at STB. It becomes clear that if STB is really serious about developing its innovation competencies, corresponding factors such as knowledge and administrative support need to be given the most attention since these factors show a significant mean of "do not know". There is also a huge gap between IT employees and non-IT employees on these two factors. Furthermore, while not dangerously alarming, management structure and technology are also worth highlighting.

Discussions and workshops were then conducted to confirm and to explore more detailed information about the internal conditions of STB. The discussion and workshop confirmed the results of the survey that had previously been conducted. The most important thing that needs to be noted is that there is a very striking gap between IT staff and non-IT staff related to their knowledge. This needs to be a top priority for STB in making improvements. In addition, the "do not know" findings regarding administrative support factors were also well confirmed. This indicates that internal consolidation, especially between IT and nonIT divisions, is also of immediate interest (Iman, 2014).

\section{CONCLUDING REMARKS AND IMPLICATIONS}

In responding to the current dynamics of fintech, several suggestions and recommendations can be implemented, such as:

(1) optimization of existing mobile and internet-based services;

(2) internal consolidation and restructuration;

(3) the initiation of fintech payment services; and

(4) the initiation of fintech lending services.

Based on the fact that the growth of Internet banking services at STB is quite exponential, it needs to be optimized to reach the critical mass. The rationale of this strategy is to cut operating costs, expand market coverage, and, more importantly, increase customer readiness for more diverse and sophisticated technology-based services. Thus, adding features can be juxtaposed with a massive marketing campaign to achieve strong network externalities (Rogers, 1995).

Second, the fact that the internal gap is still visible, especially between the IT division and the non-IT division, shows that there is an internal need for improvement. The first thing that is necessary is the change in key performance indicator (KPI) to promote collab- 
oration and innovation. Furthermore, rotation and distribution are also needed so that the knowledge held by IT division staff can be disseminated to other divisions (non-IT) as well. Another agenda that could be initiated is how incumbent banks can incorporate agility and digital mindset into the internal capabilities of their employees (Iman, 2014).

Third, if incumbent banks want to enter the fintech industry, the most feasible choice is perhaps through the payment sector. This is not only emphasized by data, but also the fact that the largest fintech service in Indonesia is still dominated by the payment sector (Iman, 2018). On the other hand, the investment and internal capabilities needed to enter this sector are not as challenging as others. This is also highlighted by the fact that STB has quite a lot of branches in the province, becoming a cash register for regional government, and has the potential to control transactions of any assets owned by the local government. Similarly, STB can also combine several regional potentials in the area such as tourism, toll roads, parking and retribution, as well as other local activities.

Furthermore, there are several sub-sectors that can be initiated by STB; for example, by becoming a custodian bank, STB has the potential to earn revenue from the floating fund. STB can also open up such payment acceptance services. Working closely with other payment gateways, the bank has the potential to get a share of fee-based income per transaction that occurs. Another thing that can be done is becoming an e-money issuer. It may, however, require extra preparation, because regulations are still restricted only for banks in the BUKU-IV category.

Fourth, other potential fintech subsectors that can be initiated by incumbent banks are financing or lending services. This is also in line with the second largest market share after the payment subsector. This sub-sector can also be strategically executed without cannibalizing the existing STB's products and services. As a first step, banks can conduct strategic cooperation together with the existing fintech service providers. Bankable customers can be channeled through existing financing products and services, while unbankable customers such as MSMEs, aspiring entrepreneurs, and individuals with no track record can be directed through STB's affiliated fintech products and services.

As for future studies, it is suggested that multilevel research through the aggregation process could be performed to analyze the different level of readiness in a various level/layer of organizations. Moreover, individual variables, such as the way in which individual performance and behavior influence organizational collective innovation capability, will be of interest. Another relevant and promising studies are comparing several firms or organizations that share similar characteristics. Last but not least, bridging the quantitative-qualitative gap is also highly encouraged. In other words, the quantitative approach like this can be accompanied by qualitative interviewing to analyze the challenges and contributing factors that affect organizational innovation capability.

\section{CONCLUSION}

All in all, as this research suggests, the development of the fintech industry is generally very massive and broad in scope (Iman, 2018). In Indonesia, the development of fintech, in particular, is also very significant, especially payment and financing subsectors. However, fintech types and business models in Indonesia are actually very diverse, ranging from payments, financing (lending), investment, crowdfunding, to back-office. Thus, the potential clash between incumbent banks and emerging fintech startups is quite eminent. This article not only analyzes the development of fintech in the country, but also looks at different scenarios and explores the possible strategies that can be developed by incumbent banks.

Using the case of STB, this study shows that the impact of fintech startups towards incumbent banks does exist. The financing subsector (lending), for example, can be considered to be the real competitor for banks. The payment sector is also influential, especially for technology start-up companies targeting the payment business (techfin), such as Go-Jek, Grab, Traveloka, and so on. The impact of such fintech's business on banking business in general and STB, in particular, is very diverse. Fintech makes the business competition market more competitive. This competition makes innovation continue to grow in the sectors (Lee \& Shin, 2018). 
In the case of STB, it becomes clear that in order to exploit the opportunities, internal capabilities of incumbent banks should be developed further. Such strategic roadmap is also needed by incumbent banks so that they have clear direction in responding to the challenge. It should also be supported by a more agile organizational structure and more flexible decision-making patterns (Iman, 2014). This is necessary so that incumbent banks can quickly develop new products and services so that it can attract customers' faster (time to market) without losing any futile momentum (Wonglimpiyarat, 2018).

Indeed, competing against new fintech startups is not the only way out. There is also equal possibilities to collaborate and partner with them. In order to ensure smooth sailing cooperation, however, focusing on each core capabilities is particularly important. Moreover, incumbent banks should find the middle ground between partnering with fintech startups versus investing or building their technology internally. Last but not least, fintech will be greatly influenced by the existing regulatory regime. When regulation tends to lean towards fintech rather than conventional banking, then the detrimental effect for incumbent banks will be increasingly felt. Thus, maintaining close relationships with central authority body should not be neglected indeed.

\section{REFERENCES}

1. Bell, E., Bryman, A., \& Harley, B. (2018). Business Research Methods. Oxford University Press.

2. Creswell, J. W. (2003). Research Design: Qualitative, Quantitative, and Mixed Methods Approaches (2nd ed.). Sage: Thousand Oaks, CA.

3. Denzin, N. K. (1989). The Research Act (3rd ed.). New York: McGraw-Hill.

4. Gomber, P., Koch, J. A., \& Siering, M. (2017). Digital Finance and FinTech: current research and future research directions. Journal of Business Economics, 87(5), 537580. http://dx.doi.org/10.1007/ s11573-017-0852-X

5. Iman, N. (2014). Innovation in financial services: A tale from e-banking development in Indonesia. International Journal of Business Innovation and Research, 8(5), 498-522. https://doi. org/10.1504/IJBIR.2014.064611

6. Iman, N. (2018). Assessing the dynamics of fintech in Indonesia. Investment Management and Financial Innovations, 15(4), 296303. http://dx.doi.org/10.21511/ imfi.15(4).2018.24

7. KPMG. (, 2015, December 14). Fintech 100: Announcing the world's leading fintech innovators for 2015. Retrieved from https:// home.kpmg/xx/en/home/media/ press-releases/2015/12/fintechannouncing-the-world-leading. html

8. Lee, I., \& Shin, Y. J. (2018). Fintech: Ecosystem, business models, investment decisions, and challenges. Business Horizons, 61(1), 35-46. http://dx.doi. org/10.1016/j.bushor.2017.09.003

9. Miles, M. B., \& Huberman, A. M. (1994). Qualitative Data Analysis: An Expanded Sourcebook (2nd ed.). Sage publication: Thousand Oaks.

10. Parasuraman, A., Zeithaml, V. A., \& Berry, L. L. (1988). SERVQUAL: A multiple-item scale for measuring consumer perceptions of service quality. Journal of Retailing, 64(1), 12-40.

11. Pricewaterhouse Cooper (PWC). (2016). Blurred lines: How FinTech is shaping financial services. Retrieved from https://www.pwc. $\mathrm{de} / \mathrm{de} / \mathrm{newsletter/finanzdienstle-}$ istung/assets/insurance-insideausgabe-4-maerz-2016.pdf

12. Rogers, E. M. (1995). Diffusion of Innovations (4th ed.). New York: Free Press.

13. Schoefield, J. W. (1990). Increasing the Generalizability of Qualitative Research. In R. Gomm, M. Hammersley, \& P.
Foster (Eds.), Case Study Method: Key Issues, Key Texts. London: SAGE Publications Ltd.

14. Snyder-Halpern, R. (2001). Indicators of organizational readiness for clinical information technology/systems innovation: a Delphi study. International Journal of Medical Informatics, 63(3), 179-204. Retrieved from https://www.researchgate.net/ publication/11843362_Indicators_ of_Organizational_Readiness_for Clinical_Information_TechnologySystems_Innovation_A_Delphi_Study

15. The Economist (2015). The FinTech revolution: A wave of startups is changing finance for the better. The Economist, 415(8937), 13-15.

16. Wonglimpiyarat, J. (2018). Challenges and dynamics of FinTech crowd funding: An innovation system approach. The Journal of High Technology Management Research, 29(1), 98108. http://dx.doi.org/10.1016/j. hitech.2018.04.009

17. Yen, H. R., Wang, W., Wei, C.-P., Hsu, S. H.-Y., \& Chiu, H.-C. (2012). Service innovation readiness: Dimensions and performance outcome. Decision Support Systems, 53(4), 813824. https://doi.org/10.1016/j. dss.2012.05.015 